\title{
THE ACTIVITY OF SOCIAL AND PSYCHOLOGICAL REHABILITATION CENTRES FOR FAMILIES IN IVANO- FRANKIVSK REGION (UKRAINE)
}

\author{
VICTORIIA STYNSKA, OKSANA TYTUN
}

\begin{abstract}
The article deals with the work of social and psychological services in Ivano-Frankivsk region (Regional Center of social and psychological help in the village Verkhovyna, district Verkhovyna, Municipal social rehabilitation center of mother and child "Mistechko myloserdia sviatogo Mykolaia", Interregional center of social and psychological rehabilitation of children in the village Medynia, district Galytskyi). The centers aim at implementation of new forms of social support of women, prevention of abandonment and child's social orphanhood, providing social, psychological, pedagogical, medical and legal assistance.

The centers carry out the activity on principles of human rights protection, humanity, legitimacy, availability, mutual respect and confidentiality.

It has been found that the centers aim at: social and psychological diagnostics; psychological and pedagogical help, social and medical care; correction-developing work; adaptation to family environment and legal assistance.

It was concluded that centers of social and psychological rehabilitation of families in IvanoFrankivsk region due to the wide range of tasks have become special places (schools) of pedagogical, psychological and medical help to the children, young people and families with children in difficult life situations.
\end{abstract}

Keywords: center of social and psychological rehabilitation, family, Ivano-Frankivsk region, Ukraine.

\section{INTRODUCTION}

Social policy is an integral part of any well-developed country. It is considered to be a criterion of social welfare of a society. At the same time, in a state of society transformation, unstable political system and bad economic situation, children, families with children and young people are the most vulnerable under all these circumstances.

The mentioned problem has not been studied yet both in historical and pedagogical sciences. However, there are some studies on origin and development of childcare system as well as studies on combating the phenomenon of street children (V. Vynogradova-Bondarenko, M. Gernet, O. Gusak, I. Diptan, A. Zinchenko, S. Kulchytsky, S. Kovalenko, D. Futer, A. Khmyrov, V. Chuba, Y. Shatalin), legal protection of children (O. Boiko, S. Havrysh, I. Zaharnytska, I. Kovchyna, L. Kushynska, 
L. Olkhovyk); providing social and pedagogical conditions for child protection (I. Zverieva, O. Karaman, V. Orzhekhovska, Zh. Petrochko, T. Yanchenko).

Thus, the challenging problem today is to develop the strategy of social policy, namely the work of social and psychological services. We should mention social services in Ivano-Frankivsk region (Regional center of responsible paternity "Krynytsia", Regional center of breast feeding support, Regional center of early development of a child "Dyvotsvit", School of paternal competence "Stanislavsky tato", Center of would be parents "Diviia", etc.). They aim at promotion and maintaining healthy way of life, planning family life, advice and support of expectant mothers. It should be noted that the work of mentioned above organizations has already been studied in scientific literature [5].

Consequently, on the basis of the adopted documents (General Regulations on social and psychological rehabilitation of children accepted by the Cabinet of Ministers of Ukraine (2004), General Regulations on social and psychological centers (2005) and others) Centers of social-psychological rehabilitation of families have been created in some regions of Ukraine.

\section{RESUlts}

Let us consider the aim and work of social services in Ivano-Frankivsk region (Regional Center of social and psychological help in the village Verkhovyna, district Verkhovyna, Municipal social rehabilitation center of mothers and children "Mistechko myloserdia sviatogo Mykolaia", Interregional center of social and psychological rehabilitation of children in the village Medynia, district Galytskyi) they carry out the activity on principles of human rights protection, humanity, legitimacy, availability, mutual respect and confidentiality.

The most common problems of the people applying for the services are: the absence of accommodation, difficult vital circumstances, social disadaptation, material and health problems, orphanhood, conflict situations with parents and violence in family, psychological crisis, undesirable pregnancy, disharmony of domestic relations, problems with communication.

In particular, there has been a Regional Center of social and psychological help since 2005 in the village Verkhovyna, district Verkhovyna, Ivano-Frankivska oblast. People in difficult vital situations (in particular families with children, young people) are living there. It is the only establishment of such type in Ivano-Frankivsk region, so people from all districts and towns of the area can shelter there. According to the regulations, Center gives help (accommodation, food, social, psychological and legal assistance) to people including with children. As well as people who have got through natural disasters and violence can apply for help there [3].

The Center has got such specialists as social teachers, psychologists, lawyers and medical staff. They provide the following services:

- Individual consultations, advice, a psychological diagnosis with a view of psychological treatment; group and interactive remedial classes, training sessions on psychological issues;

- Ensure realization of the rights of children, young people and families in a society, advise on upbringing children problems;

- The first urgent aid is given in cases of accidents;

- Carry out the protection of rights and interests of persons, give help in processing of documents;

- Give information about working time of establishments of social direction, health protection, education, center of employment, executive and organs of local self-government bodies;

- Direct persons who applied for Center, in cases of necessity, to other establishments to meet the needs of people;

- With other establishments and organizations assist extracting from the crisis state of persons that appealed to the Center [3].

The center can accommodate not more than 30 persons, thus minor children without parents are not allowed in here. The maximal term of stay is 90 days. 
An art workshop with attracting specialists in applied art has been created here; a summer recreation area is also built here; a library, a chapel are constructed here as well [3].

In 2015 special facilities for mothers with children were opened. Women with new-born children and expectant mothers who are under difficult vital circumstances can stay here [6].

Since 2006 the Ivano-Frankivsk municipal social-rehabilitation center of mothers and children named "Mistechko myloserdia sviatogo Mykolaia" has been founded (in accordance with the decision of the Ivano-Frankivsk town council of 20 February, 2006). It is the establishment of social defense of children and mothers with very young children who are in difficult life situations, who are prevented from the implementation of maternal duties; it also gives social and psychological, pedagogical, medical, legal and other types of help [2].

The primary purpose of the center is an input of new forms of social support of women, prevention of abandonment and child's social orphanhood.

In accordance with the Statute, basic tasks of the center are:

- giving its inhabitants social, psychological, pedagogical, medical, legal and other types of help;

- providing proper psychological, pedagogical and living conditions for normal life for people who are tem porally here;

- moral education of children;

- psychological, pedagogical correction work on basis of individual needs of a child;

- conditioning for education taking into account the level of their preparation;

- an assistance to obtain education, profession, learn skills for independent life with a child in conditions out of the center, protection of their rights and interests;

- an assistance to have world view for overcoming the habits of asocial behavior;

- realization of labour adaptation in accordance with the interests and abilities;

- making recommendations on social and psychological adaptation of children addressed to pedagogues and social workers and parents [4].

Specialists of the Center in accordance with the tasks must:

- organize an interview with persons who are applying, acquaint them with the rules of internal order;

- with the agreement of heads of health care establishments, be ready to give a psychological help to the women who are in obstetric-gynaecological, neonatal and pediatrics departments;

- carry out control of living conditions of people who have left the center;

- organize individual and group correction work with people living in the center, give a psychotherapy help, qualified assistance (psychological, pedagogical, medical, legal), in cases of necessity, organize their hospitalization and clinical examination;

- provide the implementation of the individual programs of adaptation, rehabilitation and reintegration in a society of persons temporally living in the center;

- drawing up a petition calling for a disciplinary and administrative responsibility of officials who are guilty in violation of rights and interests of persons tem porally living in the center;

- recording and analyzing the work done with persons temporally living in the center, prepare all the necessary statistical, informative and analytical materials.

The center consists of subdivisions dealing with:

- social, psychological and pedagogical diagnostics and rehabilitation;

- medical and preventive care;

- legal service;

- help line "Telephone of trust" [4].

The subdivision of social, psychological and pedagogical diagnostics and rehabilitations analyze the state of educational neglect of a child, assists the organs of guardianship to arrange life of the children, looks for the information on parents place of residence, gives a social and psychological help to the young mothers, helps them to be integrated in the society, get skills for caring children etc.

A medical and preventive care subdivision provides medical and preventive help: examines physical and psychical development; examines mental problems; inspects food supply, maintains 
sanitary facilities; controls pregnancy of women and provides supervision upon newborns; does awareness -raising activities on urgent issues among children, parents and personnel of the establishment.

Legal service gives the children, their parents and guardians consultations on legal questions; drawing up petitions to establishments and organizations to protect the rights and interests of mothers and children (housing, property rights etc.).

The help line "Telephone of trust" gives telephone consultations on vital questions to support livelihoods in crises [4].

In the center there are groups of 15 persons united by the same age, by family principles, character and degree of social and psychological disadaptation.

The children in difficult life circumstances are accepted to the center, the children can also be moved here from shelters for minors, or the children who suffered domestic violence and who need social and psychological help.

A child can stay in the establishment for no more than 9 months in case of stationary stay and 12 months in case of day stay. In cases of necessity their staying can be extended.

Expectant women (mothers) are accepted to the center as well. Expelling from the center comes in cases of achieving the full age; in case of acting against interests of a child; systematic breaking the rules of the establishment.

After leaving the center, a person who temporally lived here, can be taken under social guidance of social services for families, children and young people in accordance with the place of residence [4].

For the year 2016, in "Mistechko Myloserdia" at a nunnery, four sisters-nuns, 28 children (aged from 5 to 18) and 5 kids (aged up to 1) are living there. Lonely people live in another monastery "Voplochenogo Slova" near Ternopil, single mothers with children live in the village Gorokholyno, district Bohorodchany, Ivano-Frankivska oblast, they are under the care of three sisters-nuns [2].

In 2013 the Interregional center of social and psychological rehabilitation for children was founded in the village Medynia, district Galytskyi, Ivano-Frankivska oblast. It is the establishment of social defence; children from 3 up to 18 years old can stay there. They are given psychological, pedagogical, medical and legal assistance.

The main tasks of the center are:

- social defence of children and giving them social services;

- social and pedagogical correction taking into account the individual needs of a child;

- an assistance to return a child to a biological family;

- providing going to educational establishments or individual studies taking into account needs and capacities of a child;

- an assistance to form own outlook for overcoming asocial behaviour;

- giving psychological and other help to return a child to the family;

- giving recommendations on social and psychological adaptation of a child to pedagogical and social workers and parents.

The center accepts:

- the children from families in difficult life circumstances who are unable to overcome the problems on their own; if the parents do not provide the children with proper maintenance and care or fail in the duty and responsibility for the children, if the parents abuse alcohol or drugs;

- the children left without parents' care;

- in cases of child abuse and trafficking, the children are accepted;

- the homeless children.

There are 30 children in the center, for the year 2016 [1]. The center carries out its activity in the following directions: social and psychological diagnosis; social, psychological, pedagogical rehabilitation; adaptation to family environment; social and medical rehabilitation and legal assistance.

The social and psychological diagnosis aims at discovering social and psychological features of a child in order to understand mental and emotional well-being better. As a result of the first social and 
psychological diagnosis, the individual program of rehabilitation is done and directions of help are determined.

A social, psychological, pedagogical rehabilitation provides carrying out a variety of educational and advisory activities which will assist integration of a child in the society.

Adaptation to family environment envisages a deep analysis of social and emotional relations with family environment, carrying out the social and psychological rehabilitation in order to build relationships with people in the family.

A social and medical rehabilitation envisages providing a complex of measures to improve the child's health as well as mental and emotional well-being, it also provides a variety of educational and advisory activities on healthy way of life.

The legal assistance envisages establishing the identity of a child (in case of necessity), finding information about her/his family environment, informing parents about sending a child to the establishments or services dealing with children's problems, giving free legal advice and represent the legitimate rights and interests of children in courts.

\section{CONCLUSIONS}

Thus, centers of social and psychological rehabilitation of families in Ivano-Frankivsk region due to the wide range of tasks they are dealing with (social and psychological diagnosis; psychological and pedagogical help, social and medical care; correction-developing work; adaptation to family environment; legal assistance, etc.) have become special places (schools) of pedagogical, psychological and medical help to the children, young people and families with children in difficult life situations.

\section{REFERENCES}

[1] Interregional center of social and psychological rehabilitation of children in the village Medynia. Available at: http://burshtyn-rada.if.gov.ua/novyny/mizhregionalnyj-tsentr-sotsialno-psyhologichnoyireabilitatsiyi-ditej-v-ivano-frankivskij-oblasti-s-medynya/. (in Ukrainian)

[2] Saint Nicolas mercy town. Available at: http://www.mvk.if.ua/news/31359. (in Ukrainian)

[3] Regional center of social and psychological help. Available at: http://yaremche.org/news/335. (in Ukrainian)

[4] The Statute of Municipal social rehabilitation center for mother and child "Saint Nicolas mercy town". Available at: http://www.namvk.if.ua/ref_doc/26738. (in Ukrainian)

[5] Stynska V.V. Social services of maternity and child's support in Ukraine: modern challenges (in IvanoFrankivsk Oblast). Obrii, 2 (45) (2017), 126-130. (in Ukrainian)

[6] There will be a shelter for mothers and children in Verkhovyna. Available at: http://kurs.if.ua/news/u_verhovyni_stvoryat_tsentr_materi_ta_dytyny_8639.html. (in Ukrainian)

Address: Victoriia Stynska, Oksana Tytun, Vasyl Stefanyk Precarpathian National University, 57, Shevchenko Str., Ivano-Frankivsk, 76018, Ukraine.

E-mail: svt9@ukr.net, tytun_oksana@ukr.net.

Received: 29.11.2017; revised: 20.03.2018. 
Стинська Вікторія, Титунь Оксана. Діяльність центрів соціально-психологічної реабілітації сім'ї на Івано-Франківщині (Україна). Журнал Прикарпатського університету імені Василя Стефаника, 5 (1) (2018), 156-161.

У статті проаналізовано мету та завдання Центрів соціально-психологічної реабілітації сім'ї на Івано-Франківщині (обласний Центр соціально-психологічної допомоги в селищі Верховина Верховинського району, міський соціально-реабілітаційний центр матері та дитини “Містечко милосердя Святого Миколая", Міжрегіональний центр соціально-психологічної реабілітації дітей в с. Мединя Галицького району), мета яких, відповідно до напрямів діяльності, - запровадження нових форм соціальної підтримки жінок, запобігання відмові від новонароджених, попередження соціального сирітства, надання комплексної соціальної, психологічної, педагогічної, медичної, юридичної та інших видів допомоги дітям, сім'ям 3 дітьми та молодим дюдям, які опинидись у складних життєвих ситуаціях та ін. Центри провадять свою діяльність на принципах захисту прав людини, гуманності, законності, доступності послуг, конфіденційності, поваги до особистості.

Встановлено, що типовими завданнями Центрів є: соціально-психологічне діагностування; психолого-педагогічна допомога, соціально-медична реабілітація та оздоровлення; корекційнорозвивальна та корекційно-відновлювальна робота; адаптація до сімейного оточення; юридичний супровід та ін. Досліджено, що Центри соціально-психологічної реабілітації дітей на ІваноФранківщині завдяки широкому спектру завдань стали школою педагогічної, психологічної та медичної допомоги дітям, сім'ям 3 дітьми та молодим дюдям, що опинидися у складних життевих ситуаціях.

Ключові слова: Центр соціально-психологічної реабілітації, Україна, Івано-Франківщина, сім'я. 